\title{
DOES ECONOMIC INTERVENTIONISM HELP STRATEGIC INDUSTRIES? EVIDENCE FROM EUROPE
}

\author{
Anita Maček, Rasto Ovin
}

\section{Introduction}

Inward FDI should stabilize domestic income fluctuations and help investment risks in the domestic economy to disperse, at the same time enabling access to modern technology and financial sector development [8]. Thus they support a typical classical argument for international capital flows liberalization.

There are several studies showing the effects of FDI in different host countries. The earliest studies are showing the positive effects of foreign ownership on productivity in a domestic firm [2], [1]. The same conclusions were later drawn also by some other authors [11], [3]. Other studies show that FDI affect the development potential of the economy as well as reduce unemployment, affect transfer of new technologies and knowledge, generate additional tax revenue for the state, support development strategies of individual sectors, affect the development of managerial knowledge, increase engagement of local companies in supplier and subcontractor networks and generate a better utilisation of the local infrastructure and service activities [15], [5].

The benefits of FDI are not self-evident and greatly differ among different countries. The benefits from FDI are enhanced in an open investment environment with a democratic trade and investment regime, active competition policies, macroeconomic stability and privatisation and deregulation. The distribution of positive compared to the negative effects depends on the economic policy towards these processes and the entrepreneurial environment as well as other factors affecting their consequences [9]. It also often happens that positive effects of these transactions usually occur with a time lag [16].
On the other hand it is important to know, that with unfavourable conditions negative effects of FDI are often. These are especially evident in the form of reducing productivity of the host country, reducing employment, diminished R\&D intensity, increased concentration in the domestic market and the closing of companies, shrinking of the domestic stock market because shares are being transferred to a foreign stock market, anti-competitive reactions of the acquired firms, abnormally low sales prices of companies or eliminated competition in the domestic market [18], [19]. In recent years, negative effects often include also threats to national sovereignty and autonomy of the host country and thus losing control of strategic industries, whereby the threat of losing economic independence is especially emphasised [9].

In order to minimize these effects [22] requires cautious economic policy with adjustment of institutional settings and especially competition policy. Real national economic policies therefore often tend to distinguish between greenfield investment and C-B M\&A within FDI: better accepted than C-B M\&A, greenfield FDI should enable new production, employment and technology. On the other hand, C-B $M \& A$ are less stable due to greater mobility of this form of FDI and can include opportunistic capital movements. Although differences between these two forms of FDI diminish in the long term, C-B M\&A should bring the following risks to macroeconomic developments:

- Unlike with greenfield investment, with C-B M\&A a foreign corporation may buy a local company in order to exclude a competitor in an important market; 
- If it holds a sufficient market share, foreign affiliate with an intention described above may seriously harm competition in the entire domestic market;

- New owners from abroad not involved in domestic environment issues may unproportionally exercise cost reduction thus causing degradation of the acquired company;

- The takeover of the domestic firm may take place in a period of financial crisis or in other circumstances unfavorable to the domestic company, thus the selling price achieved may be too low in comparison to the company's real value;

- In the case when the subject to a bid is a large company stock markets may shrink as through the C-B M\&A deal shares have been collected from the domestic public [17].

In $1987,90 \%$ of all inward C-B M\&A were realized in industrial countries. Owing to their stronger and stronger incorporation into world trade and capital mobility in the 1990s developing and transition countries became more and more important locations for inward C-B M\&A and in 2012 they reached almost $23 \%$ of global C-B M\&A flows [20]. Despite their relatively higher level of capital saturation compared with developing and transition countries, developed countries retain their dominant position in world C-B M\&A also as host countries. After they stabilized on $80 \%$ of global inward C-B M\&A level towards the end of last decade and losing some pace in 2010 and 2011 (about 75\%) the last accessible data 2012 demonstrated their even stronger lead (84\%). When taking an example of the EU developed countries such developments are in accordance with expectations basing on better state of their economies regarding stock market capitalization, value addition and the condition of the regulatory and financial institutional setting [16]. Apart from the fact that developed countries are retaining their leading position in EU economy one should, however, note that dimension (consolidation of industries) and dynamics of C-B M\&A transactions have progressively earned structural character in their economies. As proven in several analyses traditional leaders of trade and international capital transactions are more and more experiencing the impact of C-B M\&A on their economic goals (employment, balance of payments, industrial structure) [10], [12]. These developments bring new experience to the EU developed countries' governments: they are often put into position when their national economic policy makers seem to lose the control over economic goals and especially nationally important or strategic companies or even industries. The above facts support the expectations that the liberalization of international capital mobility within the EU adds to the concerns of national governments. So it is no surprise that it took long lasting process to come to a minimum agreement of international capital mobility rules in the EU common market. Before it was adopted in 2004 it took member countries about 17 years to meet a minimum agreement formalized by the Directive on Takeover bids. Although being formalized in the form of Directive the rules did not prove sustainable from the very beginning and so European capital market in the years after 2004 experienced considerable national economic policy interventions expressing short term view on economic goals fulfillment.

In this article authors discuss the issue of C-B M\&A from the point of the lesson that the European evidence could represent to economic policy of an economy, which is shaping its cohabitation in the EU and is eager to steer its economic policy towards reducing its gap towards developed EU industrial countries. It starts with presentation of some of the most known cases of interventionism in Europe after the adoption of EC Directive on takeover bids in 2004. After brief presentation of the results of the Takeover Directive in the first chapter, in the second chapter authors present results of a study measuring economic effects of inward C-B M\&A in Europe. By combining the data about economic effects from the study with the data of investment freedom as prepared by Heritage Foundation in 2009 and 2014, authors analyse if strategic sectors benefit from incoming C-B M\&A when subject to the previous market oriented industrial policy. The last chapter brings conclusions.

\section{Empirical Phenomena}

Although liberalization of international capital flows was formally legalized in the EU with the Treaty of Maastricht in 1994, the most relevant 


\section{Ekonomie}

for C-B M\&A within the EU is the Directive 2004/25/EC of the European Parliament, and of the Council on Takeover Bids (2004). Despite the fact that the years preceding 2004 were marked by dynamic integration processes between European states, it took 17 years (!) until the text of the directive was acceptable enough so as to be adopted by the EU member states. This is the consequence of the fact that the member states wanted to keep the right to individually define mechanisms for protecting important domestic companies from takeovers after implementing the new EU legislative [6].

Soon after legalization in 2004 the takeover Directive already triggered the concern of European national governments that their national industrial policy supporting other economic goals would be out of control. Foreign spectators warned that the attitude of real economic policy of European governments demonstrated economic nationalism. According to [14] "There is a neo-nationalism in Europe... they don't even believe in their own project. They say they want a big market for capital and goods, but when it doesn't go well, they resort to neoprotectionism." The attitude of the EU governments came out to be the protection of "national champions" - an expression was assigned to the French Prime Minister De Villepin (2005-2007), who deliberately acted against foreign companies' bids for some important French companies. So he prevented an Italian bid for the French water and energy company Suez, and an American bid for the French food empire Danone.

Also, other European countries in the period between 2005 and 2006 offered typical examples of reviving economic nationalism. German chancellor Angela Merkel personally prevented the bid of Russia Sistema for a share in the national telephone service provider Deutsche Telekom. In Italy the bid for a takeover of highway company Autostrade by Spanish Albertis was disabled. In Spain, accompanied by political arguing, the takeover of electric company Endesa by German E.ON was brought to a halt. In Italy an attempt for considerable foreign investment into national telephone service provider Telecom Italia by American AT\&T and Mexican America Movil was stopped due to internal political disagreement. Some studies are presenting the concrete cases on interventionism of individual countries and clearly show the defence policy of developed host countries when dealing with C-B M\&As in strategic industries [13].

The engagement of most important European economies in these processes, however, differed substantially. According to the IMF in 2006 FDI represented about 13\% of GDP in Italy, $25 \%$ in Germany, $36 \%$ in Britain, and $42 \%$ in France. These figures obviously explain why the French government seems to be the most active with protecting their "national champions." On the other hand, however, a lack of such striking examples from Britain despite relatively high share of FDI if compared to their GDP, characterizes the typical Anglo-Saxon attitude of an open economy.

When judging the actions of EU member states' governments, however, one should note that after the adoption of the EU Directive on takeover bids obviously the era of fast growth of inward FDI in the EU has started. So with respect to 2004 and 2005 the growth of FDI as a percentage of gross fixed capital formation in the EU was $125 \%$, while in the same period it grew in developed countries of the world for $41 \%$. Also, in the top 50 pairs of countries with the largest bilateral inward stock, in 200522 were from Europe, compared to 17 in 1995 [19]. Considering this and adding quite a high ranking of employment goals and statesupported social cohesion in continental Europe, we should not be surprised that reactions previously described came from ruling parties - coalitions regardless their political orientation.

After eight years of its application the EU Commission analysed the effects of takeover Directive (2012). According to the analysis the Directive did not led to major changes in the member states legislative - allegedly also because of the fact that changes in member countries framework have already been in process in the time of the Directive adoption. As to the transposing of the whole Directive the actions of member states differ quite a lot. While the board neutrality rule ("prevents any action by the company, which could frustrate the bidder without authorization by the general shareholder meeting") was adopted by 19 member states, only three of them transposed the breakthrough rule ("neutralizes the pre-bid defenses during the takeover by making them inoperable during the takeover period) and half 
of the states allow the home companies who are subject to a foreign bid, not to apply the two rules mentioned, when the foreign offer or is not subject to the same rule - reciprocity. Nevertheless the analysis states that the shareholders in general believe that the Directive made a difference in the field of coordination that it has strengthened the position of minority shareholders and it improved the disclosure regime. Relevant for the political market exchange and thus influencing economic policy practice is the reluctance towards the Directive by the representatives of employees, stating that the document does not sufficiently protect employees against changing conditions and layoffs after the takeover. In this way the analysis of the Directive implementation points to the fact that the choice of national policies to intervene in the field of intra EU capital movements still exists.

\section{Empirical Study on Consequences of the Directive}

\subsection{The Data, Sample and Method}

The research presented in this article is based on the analysis of the relationship between economic effects of C-B M\&A and Heritage Foundation Index of Investment Freedom. An international study of C-B M\&A's economic effects at the national level was carried out using the method of total analysis. It deliberately considers answers from a survey carried out in chosen academic communities in 2009 because five years after the adoption of Takeover Directive the estimates from academic community were considered to be the most realistic. In the research we presupposed that academic view on economic effects of inward C-B M\&A in their home country would stay relevant for at least mid-term period, here meaning 5-10 years, as one of the academics' mission is to retain robust position with current issues of economic policy. The research was carried out through estimation of two equations. With the first one the relationship between results of a study 2009 (especially government intervention and economic position of strategic sectors) and Index of Investment Freedom for 2009 and with the second one the relationship between results of a study 2009 and the same Index for 2014 was tested.
Respondents in the survey from 2009 were professionals from business schools, who in one way or another are following real practice in the field in their home countries. In our research, we considered the respondents' view as typical and respectively representative for the country in which business school is located. This could include the risk of a personal bias. However, the respondents were invited to participate by individual schools' deans according to their field of research and teaching. As a rule they were in one way or another actively involved in the field of C-B M\&A in their countries, or were at least well-acquainted with professional or public discussion on the matter in local circles and in the media.

In this way the quality of answers does not lag behind the quality of answers obtained in other known studies using a similar methodology. One that should be mentioned is the analysis of public sentiment with Norway bank takeover by analyzing printed media [21]. The methodology used is to a certain extent comparable with the study of European Group for Investor Protection [4], where answers are obtained by interviewing government officials in individual states, and with the study of Global Financial Communication Network [7] where authors rely on the opinion of editors and top journalists on C-B M\&A effects. Considering the types of involvement of respondents in our study, one could rate the method used less prone to political or popular bias.

The study 2009 was carried out with the help of a questionnaire consisting of 21 questions in the fields of macroeconomic and microeconomic effects of inward C-B M\&A in European economies.

The sample included 109 business schools from the following 36 countries (the number of respondents is in parentheses): Austria (4), Belarus (2), Belgium (2), Bosnia and Herzegovina (2), Bulgaria (2), Croatia (4), Cyprus (2), Czech Republic (4), Denmark (2), Estonia (2), Finland (2), France (2), Germany (3), Georgia (2), Greece (2), Hungary (4), Ireland (2), Italy (3), Island (2), Latvia (3), Lithuania (6), Netherlands (2), Norway (2), Poland (4), Portugal (2), Romania (4), Russia (4), Slovakia (3), Slovenia (4), Spain (5), Serbia and Montenegro (2), Sweden (2), Switzerland (2), Turkey (4), UK (3) and Ukraine (4). In most parts of this research, we divided these countries into two groups: 


\section{Ekonomie}

developed countries and transition countries. As developed countries we have considered old EU members before 2004 EU enlargement, Island, Norway and Switzerland plus Turkey. Although there are considerable differences among them, these countries have been experiencing western type of democracy, market economy and private ownership. They are: Austria, Belgium, Cyprus, Denmark, Finland, France, Germany, Greece, Ireland, Italy, Island, Netherlands, Norway, Portugal, Spain, Sweden, Switzerland, Turkey and UK. On the other side as transition countries considered are European countries and Russia, who after World War II shared state ownership, central planning and mono-party system. We presupposed that these heritages should define a different need for privatization, to replace obsolete capacities in manufacturing and to develop markets and hierarchies typical for a market economy - all being normal consequences of inward C-B M\&As. The countries representing this group are: Belarus, Bosnia and Herzegovina, Bulgaria, Croatia, Czech Republic, Estonia, Georgia, Hungary, Latvia, Lithuania, Poland, Romania, Russia, Slovakia, Slovenia plus Serbia and Montenegro.

For statistical analysis the program SPSS-X for Windows and Microsoft Excel were used. By using linear regression the compatibility of the results from the questionnaire was as already mentioned tested with Index of Economic Freedom as a part of Index of Economic Freedom by the Heritage Foundation (for years 2009 and 2014). The results of the study were considered compatible to the index mentioned above as the equation coefficients were statistically significant.

\subsection{Main Results about Economic Effects}

The statistical source related to macroeconomic consequences consists of eight sets of questions referring to benefits and threats that inward $C-B$ M\&A caused in receiving economies.

When benefits are concerned, the strongest statistical significance was in both groups of countries assigned to market access and know-how, followed by technology transfer. Respondents in transition countries stressed relative to those from developed countries stronger pressure of international investors on national economic policy. The most important threats to transition countries were the crowding-out of domestic companies by foreign bidders and insufficient price achieved for sold domestic companies. Those two threats were also quite strongly present in developed countries, however with substantially lower importance relative to transition economies.

An analysis of microeconomic effects shows divergent results for both groups of countries to a certain extent. For developed countries the biggest benefit of $C-B$ M\&A proved to be the consolidation of strategic sectors, while the reduction of domestic firms' capital was on the top on the list as a threat. In transition countries the consolidation of strategic sectors was also considered on the top of benefits, while as the top threat informal pressure of foreign investors on market conditions. This effect of C-B $M \& A$ registered in developed countries quite a low value. The less present effect in both groups of countries here was contraction and the closing of R\&D departments of firms acquired from foreign companies. Among microeconomic effects also the forms of acculturation with inward C-B M\&A were analyzed. With $62 \%$ (transition countries) and $67 \%$ (developed countries) the biggest weight was assigned to integration as a form of acculturation. Readiness for assimilation in transition countries (36\% vs. $29 \%)$ was expectedly higher than in industrial countries, while separation was quoted as an exception in both groups of countries.

In general, the obtained results of the study enable us to conclude that despite differences between both groups of economies with inward FDI in the form of C-B M\&A in 2009 mostly positive effects in both countries were present. These findings diverge from real policies of industrial states described above.

Theory and own research in this way lead to the conclusion that when subject to consistent marked founded industrial policy the strategic sectors should benefit from C-B $M \& A$ as these transactions would help industry consolidation. Unlike rational industrial policy that would through supporting market adjustment strengthen strategic sectors, rather mercantilist state sheltering of these sectors would lead to unwanted sensibility. We tested this thesis and are presenting the results below. 


\subsection{Is Protectionism Serving Nationally Important Companies?}

For testing the relationship between consistent market adjusted industrial policy and the C-B M\&As' effects on strategic sectors, we exposed the results of the 2009 study to the Heritage Foundation Index of Economic Freedom Index of Investment Freedom (IIF) for the same economies in the same year. Following the midterm character of the data collected with the questionnaire for the study 2009 we took the latest IIF indicators for the year 2014 and included them in to the equation together with the indicators of economic effects of C-B M\&As as estimated by the academics interviewed five years ago. In this way the statistical and analytical quality of the first equation which should provide us with stylized facts was proved. For the subjects of economic policy in European countries - and especial transition ones confirmation of the article thesis would be of help when judging political decisions with their industrial policy.

As already mentioned we first started with the analysis using the IIF for 2009. Our expectation was that less frequent the intervention of governments in the C-B M\&A processes in order to protect the domestic economy and shareholders cause an increase in the free flow of investment. Therefore the model in the form:

$$
Y=\beta_{0}-\beta_{1} x_{1}+\beta_{2} x_{2}
$$

was expected. The following variables were included in the model:

- INDEX $X_{\text {IIF(2009) - Index of Investment }}$ freedom for chosen economies in 2009;

- $G$ l - government intervention in the C-B $M \& A$ processes in order to protect the domestic economy and shareholders;

- $S E$ - Strengthening of the economic position of strategic sectors as a consequence of C-B M\&A

The scatter plots indicated a good linear relationship between INDEX IIF $_{\text {and GI plus SE. }}$ So as to estimate a linear regression equation we carried out econometrical tests using variables provided by the study 2009 together with INDEX IIF. The results are organized in the following three tables. Table 1 below shows the multiple linear regression model summary and overall fit statistics.

\section{Tab. 1: Multiple linear regression summary}

\begin{tabular}{c|c|c|c|c|c} 
Model & R & R Square & $\begin{array}{c}\text { Adjusted R } \\
\text { Square }\end{array}$ & $\begin{array}{c}\text { Std. Error of the } \\
\text { Estimate }\end{array}$ & Durbin-Watson \\
\hline 1 & $.493(\mathrm{a})$ & .243 & .194 & .15586 & 2.170 \\
\hline
\end{tabular}

Source: own

Table 1 brings multiple linear regression summary. The adjusted $\mathrm{R}^{2}$ in our model was 0.194 with the $R^{2}=0.243$. Thus, the linear regression explains $24.3 \%$ of the variance in the data. The Durbin-Watson test $d=2.170$ was between the two critical values of $1.5<\mathrm{d}<$ 2.5 , and therefore it can be assumed that there was no first order linear autocorrelation in our multiple linear regression data.

Table 2 shows the results of ANOVA F-test.

\section{Tab. 2: ANOVA F-test}

\begin{tabular}{ll|c|c|c|c|c}
\multicolumn{1}{c|}{ Model } & Sum of Squares & df & Mean Square & F & Sig. \\
\hline 1 & Regression & .241 & 2 & .121 & 4.968 & $.013(\mathrm{~b})$ \\
\hline Residual & .753 & 31 & .024 & & \\
\hline Total & .994 & 33 & & & \\
\hline
\end{tabular}




\section{Ekonomie}

The ANOVA F-test in Table 2 includes the null hypothesis that there is no linear relationship between the variables. F-test is highly significant (the $P$-value for the $\mathrm{F}$ test statistic is less than 0.05 , thus providing strong evidence against the null hypothesis). In this way we can assume that a linear relationship between the variables in our model exists. Table 3 shows coefficients of linear regression.

\section{Tab. 3: Coefficients}

\begin{tabular}{|c|c|c|c|c|c|c|c|c|}
\hline & \multirow{2}{*}{ Model } & \multicolumn{2}{|c|}{ Unstandard. Coefficients } & \multirow{2}{*}{$\begin{array}{c}\text { Standard. } \\
\text { Coeffic. }\end{array}$} & \multirow{2}{*}{$t$} & \multirow{2}{*}{ Sig. } & \multicolumn{2}{|c|}{ Collinearity Statistics } \\
\hline & & B & Std. Error & & & & Tolerance & VIF \\
\hline \multirow[t]{3}{*}{1} & Constant & .630 & .128 & & 4.908 & .000 & & \\
\hline & $\mathrm{Gl}$ & -.067 & .027 & -.382 & -2.446 & .020 & .999 & 1.001 \\
\hline & SE & .067 & .033 & .323 & 2.065 & .047 & .999 & 1.001 \\
\hline
\end{tabular}

a Predictors: (Constant), GI,SE

b Dependent Variable: INDEX $\mathrm{IIF}_{\text {(2009) }}$

Source: own

Beta coefficients from the Table 3 express the relative importance of each independent variable in standardized form. We found that GI and SE are significant predictors and that $\mathrm{Gl}$ has a higher impact on the INDEX $\operatorname{IIF(2009)}_{\text {than }}$ SE (beta $=-0.382$ and beta $=0.323$ ). In the Table 3 also a multicollinearity test for our model is presented. As the tolerance should be $>0.1$ (or VIF statistics should be $<10$ ) for all included variables, this requirement was fulfilled with achieved VIF values 1.00.

The coefficients obtained above give the following equation:

$$
\begin{aligned}
I N D E X_{I I F(2009)} & 0.630-0.067 G I+0.067 S E \\
& (0.000)(0.020)
\end{aligned}
$$

Equation (2) shows that less frequent the intervention of governments in the C-B M\&A processes in order to protect the domestic economy and shareholders cause an increase in the free flow of investment. On the other hand, strengthening of the economic position of strategic sectors as a consequence of $C-B$ $M \& A$, increases the value of $\operatorname{INDEX} X_{I I F(2009)}$. According to these results the best solution for strategic enterprises should be to enable them to open to the international economic environment.

The second step of our research was testing the results of the study with the IIF 2014. The main aim of this step was to check whether judgments of the academic community to which mid-term relevance was ascribed could be considered relevant also after five years following the real experience as basis of their judgement. The thesis here was the same is it was for IIF 2009. We expected that values of descriptors in the linear equation will not differ essentially from the ones in 2009.

Below we present the main results and respectively descriptive statistics for the equation for the IIF data for 2014. Table 4 presents model summary.

\section{Tab. 4: Model summary}

\begin{tabular}{c|c|c|c|c|c} 
Model & R & R Square & $\begin{array}{c}\text { Adjusted } \\
\text { R Square }\end{array}$ & $\begin{array}{c}\text { Std. Error of the } \\
\text { Estimate }\end{array}$ & Durbin-Watson \\
\hline 1 & $.541(\mathrm{a})$ & .292 & .247 & .15859 & 1.920 \\
\hline
\end{tabular}

Source: own

The determination coefficient $\mathrm{R}^{2}=0.292$ from Table 4 shows that the linear regression explains $29.2 \%$ of the variance in the data. The value of the Durbin-Watson test is 1.920 , so there is no first order linear autocorrelation in our multiple linear regression data. The results from ANOVA F-test are presented in the Table 5. 
Tab. 5: ANOVA F-test

\begin{tabular}{ll|c|c|c|c|c}
\multicolumn{1}{c|}{ Model } & Sum of Squares & df & Mean Square & F & Sig. \\
\hline 1 & Regression & .322 & 2 & .161 & 6.404 & $.005(\mathrm{a})$ \\
\hline Residual & .780 & 31 & .025 & & \\
\hline Total & 1.102 & 33 & & & \\
\hline
\end{tabular}

Source: own

ANOVA F-test from Table 5 is highly significant $(F=6.404, P=0.005)$, thus we can assume that there is a linear relationship between IG, SE, and INDEX ${ }_{\text {IIF(2014) }}$. In Table 6 coefficients for regression are presented.

\section{Tab. 6: Coefficients}

\begin{tabular}{|c|c|c|c|c|c|c|c|c|}
\hline & \multirow{2}{*}{ Model } & \multicolumn{2}{|c|}{ Unstandard. Coefficients } & \multirow{2}{*}{$\begin{array}{c}\text { Standard. } \\
\text { Coeffic. } \\
\text { Beta }\end{array}$} & \multirow{2}{*}{$t$} & \multirow{2}{*}{ Sig. } & \multicolumn{2}{|c|}{ Collinearity Statistics } \\
\hline & & B & Std. Error & & & & Tolerance & VIF \\
\hline \multirow[t]{3}{*}{1} & Constant & .620 & .131 & & 4.747 & .000 & & \\
\hline & $\mathrm{Gl}$ & -.064 & .028 & -.351 & -2.320 & .027 & .999 & 1.001 \\
\hline & SE & .093 & .033 & .423 & 2.796 & .009 & .999 & 1.001 \\
\hline
\end{tabular}

a Predictors: (Constant), GI, SE

b Dependent Variable: INDEX IIF(2014) $_{2}$

Source: own

In the Table 6 we see that IG and SE are significant predictors. Values of VIF test proves that no multicollinearty exists. Following these results the equation including all previous presented variables is:

$$
\begin{aligned}
I N D E X_{I I F(2014)} & =0.620-0.064 G I+0.093 S E \\
& (0.000)(0.009) \quad(0.027)
\end{aligned}
$$

Equation 4 supports the thesis presented above. It demonstrates that with less intervention of governments in the C-B M\&A the value of Index of Investment Freedom is higher. At the same time the higher value of index is explained with improvement of strategic sectors' economic position. Better value of the index thus demonstrates better environment for strategic sectors development. The significance of the Gl variable demonstrates economic policy attitude towards protection of domestic shareholders and companies in general. Here as the matter of fact domestic and international transactions cannot be distinguished and so less discretionary economic policy approach means less intervention also in the field of
C-B M\&A. This, however, supports the conviction that national economic policy reaction on inward C-B M\&A flows also reflects the economic freedom in a given economy.

Following to the fact that between the two equations only irrelevant differences in descriptors as well as with statistics appear, we can conclude that the (explanatory) variables obtained through 2009 study approach are relevant and that the thesis could be confirmed even after almost five year time span.

This could be therefore of use for consideration by the national governments especially in European transition and preaccession countries.

\section{Conclusions}

Although most of studies prove positive effects of C-B M\&A we should be aware that these processes, when big enough, may influence economic goals of a country. With typically interventionist style of economic policy in biggest continental EU economies (Germany, France, Italy, Spain) the FDI often proves to be 
a source of disharmony between government and businesses.

The revival of interventionism (including elements of economic nationalism) in Europe might have been triggered by the liberalization of international capital flows after adopting the EU Directive on takeover bids in 2004. Activist reaction of the most important EU governments except for Great Britain in this way actually demonstrated that when goals of economic growth and employment are concerned, they rely rather to their control over nationally important sectors and companies than to the opening of the economy.

Our study on inward Cc-B M\&A in Europe proves that the interested (academic) community has judged benefits and threats of C-B M\&A much less critical than real economic policy. In order to prove which standing is closer to the facts, an additional analysis by introducing existing international FDI indicators was carried out. By using models, where our results were combined with the Index of Investment Freedom (Heritage Foundation), we carried out linear regression.

With the first equation the relationship between results of a study 2009 and Index of Investment Freedom for 2009 and with the second one the relationship between results of a study and the same Index for 2014 was tested. As academics' mission is also to retain robust position with current issues of economic policy we presupposed in the research that their view on economic effects of inward C-B $M \& A$ in their home country would stay relevant for at least mid-term period, here meaning 5-10 years.

The obtained equations for both periods were almost identical. As despite the financial and economic crisis the IIF was not subject to notable changes it enables us to conclude that nothing significant also happened in the field of the C-B M\&A economic effects for the host economies, that would trigger economic policy protectionist action. Of course this again would be offset in the individual countries' IIF value, which did not happen.

We can conclude that according to our research C-B M\&A should promote a consolidation of strategic sectors, thus suggesting that the openness of countries has positive consequences for the development of these sectors. So basing on these results we can assume that once, establishing themselves as strategic sectors and companies - the latter gains on economic strength when involved in free international capital flows and when government intervention for their protection and for protection of their shareholders is reduced.

\section{References}

[1] BLOMSTROM, M. and PERSSON, H. Foreign Investment and Spillover Efficiency in an Underdeveloped Economy: Evidence from the Mexican Manufacturing Industry. World Development. 1983, Vol. 11, No. 6, pp. 493-501. ISSN 0305-750X.

[2] CAVES, R.E. Multinational firms, Competition and Productivity in Host-Country Markets. Economica. 1974, Vol. 41, No. 5, pp. 176-193. ISSN 1468-2702.

[3] DRIFFIELD, N. The Impact on Domestic Productivity of Inward Investment in the UK. The Manchester School. 2001, Vol. 69, No. 1, pp. 103-119. ISSN 1467-9957.

[4] EGIP. European Group for investor protection [online]. 2005 [cit. 2007-09-22]. Available from: http://www.egip.org/root/index.php?page_id=128.

[5] ESTRIN, S., HUGHES, K.S. and TODD, S. Foreign Direct Investment in Central and Eastern Europe: multinationals in transition. London: Royal Institute of International Affairs, 1997. 276 p. ISBN 978-1855674813.

[6] FRESHFIELDS BRUCKHAUS DERINGER. Public takeovers in Europe [online]. 2006 [cit. 2007-05-04]. 56 p. (PDF). Available from: http://www.freshfields.com/uploadedFiles/SiteWid e/Knowledge/Public\%20takeovers\%20in\%20 Europe.pdf.

[7] GFC/NET. Economic Patriotism/Nationalism Likely to Intensify According to Business Journalists Worldwide. Business Wire [online]. Global Financial Communication Network, 2007 [cit. 2007-12-09]. Available from: http://www. allbusiness.com/trade-development/tradedevelopment-fi nance/5420005-1.html.

[8] KAMINSKY, G.L. International Capital Flows, Financial Stability and Growth. DESA Working Paper [online]. 2005, No. 10 [cit. 2007-03-05]. 24 p. (PDF). Available from: http://www.un.org/ esa/desa/papers/2005/wp10_2005.pdf.

[9] LIN, C.H. Role of Foreign Direct Investment in Telecommunication Industries: A Developing Countries' Perspective. Contemporary Management Research. 2008, Vol. 4, No. 1, pp. 29-42. ISSN 1813-5498. 
[10] LIPSEY, R.E. Interpreting Developed Countries' Foreign Direct Investment [online]. National Bureau of Economic Research, 2000. Working paper No. 7810 [cit. 2007-05-04]. Available from: http://www.nber.org/papers/w7810.

[11] LIU, X., SILER, P., WANG, C. and WEI, Y. Productivity Spillovers from Foreign Direct Investment: Evidence from UK Industry Level Panel Data. Journal of International Business Studies. 2000, Vol. 31, No. 3, pp. 407-425. ISSN 0047-2506.

[12] MAČEK, A. Čezmejne združitve in prevzemi kot dejavnik tranzicije $v$ EU. Doktorska disertacija. UM, Ekonomsko-poslovna fakulteta. (CrossBorder Mergers and Acquisitions as a Factor of the Transition in the EU - a doctoral thesis, University of Maribor, Faculty of Economics and Business). 2009.

[13] MARCHICK, D.M., SLAUGHTER, M.J. Global FDI policy: correcting a protectionist drift [online]. Council on Foreign relations, 2008. CSR No. 32 [cit. 2008-06-15]. Available from: www.cfr.org/ content/publications/attachments/FDI_CSR34.pdf. [14] PAPE, E., DICKEY, C. Rising Barriers; French Prime Minister Dominique De Villepin Is Leading a New Wave of Protectionism-In Europe-But Also, Possibly, One of Reform. Newsweek international. 2006, March 20. ISSN 0163-7053.

[15] PEREZ, T. Multinational Enterprises and Technological Spillovers. Amsterdam: Harwood, 1998. ISBN 90-5702-295-8.

[16] REISEN, H. After the Great Asian Slump: Towards a Coherent Approach to Global Capital Flows. Policy Brief. Paris: OECD Development Centre. 1999, No. 16. ISSN 2077-1681.

[17] TANDON, Y. M\&A is takeover of firms in north, economies in south [online]. Geneva: Third world network, 2000 [cit. 2005-02-04]. Available from: http://www.twnside.org.sg/title/firms.htm.

[18] TSANG, M., HAUCK, D. Stock Markets Contract as M\&A Overtakes Equity Sales [online].
Bloomberg, 2007-01-08 [cit. 2009-01-09]. Available from: http://www.bloomberg.com/apps/ news?pid=newsarchive\&sid=a7leW7BtD0dQ.

[19] UNCTAD. World Investment Report 2007. Transnational Corporations. Extractive Industries and Development [online]. United Nations: UNCTAD, 2007 [cit. 2012-08-05]. Available from: http://unctad.org/en/pages/PublicationArchive.asp $\mathrm{x}$ ?publicationid $=724$.

[20] UNCTAD. World Investment Report 2013. Global value chains: investment and trade for development [online]. New York and Geneva: United Nations. UNCTAD, 2013 [cit. 2014-03-02]. Available from: http://unctad.org/en/pages/ PublicationWebflyer.aspx? publicationid $=588$.

[21] VAARA, E., TIENARI, J., SAURI, N., BJOERKMAN, I. Global Capitalism Meets National Spirit: Discourses in Media Texts on a CrossBorder Acquisition. The 2nd Critical Studies Conference [online]. Manchester, 2001 [cit. 2004-09-11]. 21 p. (PDF). Available from: http://www.mngt. waikato.ac.nz/ejrot/cmsconference/2001/Papers/L anaguage\%20of\%20New\%20Capitalism/Vaara.pdf. [22] WYPLOSZ, C. How Risky is Financial Liberalization in the Developing Countries? CEPR Discussion Paper [online]. Geneva: University of Geneva, 2001 [cit. 09-01-2007]. Available from: http://www.cepr.org/pubs/dps/DP2724.asp.

Anita Maček, Ph.D. Doba Faculty of Applied Business and Social Studies Maribor anita.macek@net.doba.si

Rasto Ovin, Ph.D. University of Maribor Faculty of Economics and Business rasto.ovin@uni-mb.si 


\section{Abstract}

\section{DOES ECONOMIC INTERVENTIONISM HELP STRATEGIC INDUSTRIES? EVIDENCE FROM EUROPE}

\section{Anita Maček, Rasto Ovin}

Although most studies proves that Cross-Border Mergers and Acquisitions (C-B M\&A) cause more benefits than threats, the real economic policy in the $E U$ countries offsets the fear that liberalization of inward $C-B M \& A$ would endanger economic position of strategic industries and thus national economic goals.

After the adoption of EU Directive 2004/25/EC on Takeover Bids the era of fast growth of inward $C-B M \& A$ in the $E U$ and consequently the era of rising interventionism so as to protect national strategic industries and companies has started. Additional stimulus for the European Union's (EU) most developed economies to exercise interventionism was financial and economic crisis starting in 2008. Considering high ranking of employment goals and state-supported social cohesion in continental Europe, it is not surprise that interventionist reactions came from ruling parties and coalitions regardless their political orientation.

$B y$ the help of the results of their 2009 empirical study on C-B M\&A authors tested the relation between the results referring to $C-B M \& A$ effects on strategic sectors and the Heritage Foundation Index of Investment Freedom. With combining the results from 2009 study with Index of Investment Freedom from 2009 and in the second equation with index from 2014 authors checked if strategic sectors benefit from incoming $C-B M \& A$ when subject to the previous market oriented industrial policy.

Both estimated equations proves that unlike with sheltering economic policy, when subject to market conform measures of industrial policy, strategic sectors will benefit from inward $C-B M \& A$. By proving the statistical significant relationship between the results from 2009 study and Index from 2014 authors also proved the statistical and analytical quality of the equation from 2009. By proving statistical significance of the second equation we proved that the judgement of the academic community could be considered relevant also after five years following the real experience as basis of their judgement.

Key Words: Cross-border mergers and acquisitions, economic interventionism, strategic industries.

JEL Classification: C3, E2, F2.

DOI: 10.15240/tul/001/2014-3-001 